\title{
The Myths and Moral Economies of Digital ID and Mobile Money in India and Myanmar
}

\author{
JANAKI SRINIVASAN \\ INTERNATIONAL INSTITUTE OF INFORMATION TECHNOLOGY BANGALORE \\ ELISA OREGLIA \\ KING'S COLLEGE LONDON
}

\begin{abstract}
The diffusion of major new technologies in society is often accompanied by a set of myth that tell us how these technologies will change, clearly for the better, the social and economic fabric of a community. Digital technologies are associated with myths such as the death of distance and of mediators, the end of history and of politics (Brown and Duguid 2000; Mosco 2004). We build on Mosco's idea of myth as a force shaping discourses around the introduction of new technologies in the context of the deployment of digital artifacts such as digital ID systems and mobile money platforms in the Global South (Mosco 2004). Using the examples of the Unique Identification system (Aadhaar) in India and mobile money in Myanmar, we show how these myth persist long after technologies are in common use. We also examine how, in practice, the use of these technologies seldom aligns with the mythology surrounding them, and it is, instead the moral economy of the communities where they are deployed that mediates their use (Thompson 1971). We argue that local histories of state-making and the larger political economy of technology design can help explain the persistence of the mythology around digital technologies despite the disconnect between myths and reality.
\end{abstract}

\section{Keywords}

moral economy; techno-optimism; digital ID; mobile money; mythmaking

\section{Introduction}

Myths accompany the diffusion of major new technologies in society; they tell us how these technologies will change and enhance the social and economic fabric of a community. The railways were perceived as a modernizing and civilizing force, while the telegraph was to usher in an era of world peace (Adas 1990; Headrick 1981; Headrick 1988; Nye 1992, 1996; Standage

Janaki Srinivasan, Email: janaki.srinivasan@iiitb.ac.in

Elisa Oreglia, Email: elisa.oreglia@kcl.ac.uk

Copyright (C) 2020 (Janaki Srinivasan, Elisa Oreglia). Licensed under the Creative Commons Attribution Non-commercial No Derivatives (by-nc-nd). Available at estsjournal.org. 
1999). Digital technologies too are associated with myths that have helped build and consolidate a positive perception of their inevitable disruptive power. In his landmark study of the cultural origins of the digital age, Vincent Mosco argues that "myth-making," that is, the existence of myth-like narratives about new technologies and their benefits, is an important part of the introduction of such technologies around the world. He further suggests that the actual potential of any technology is truly realized only after it has lost its novelty and entered "the prosaic world of banality" (Mosco 2004). We build on Mosco's idea of myth as a force shaping discourses around the introduction of new technologies. We are especially interested in "the death of distance" and "disintermediation" myths that have continually accompanied the introduction of digital technologies. Drawing from existing literature and our own work in India and Myanmar, where digital technologies have been deployed with much emphasis on their potential to fix long-standing structural issues, we show how myths have shaped the diffusion of these digital technologies and how this diffusion has, in turn, been mediated by the "moral economy" of the communities where these technologies were deployed (Thompson 1971). We show that despite the disconnection between myths and reality, the myths persist long after the initial myth-making phase. We further argue that which myths fade and which blossom is actively shaped by local histories of state-making and the larger political economy of technology design.

The first part of this paper introduces how myth-making creates expectations about digital technologies; it then shows how the specific myths of "death of distance" and "disintermediation" encounter local moral economies in India and Myanmar. It illustrates the mismatch between the myths that circulate about the potential of these technologies to transcend place and intermediaries, and their actual working in communities. The second part of the paper discusses why, despite this mismatch, the myths continue to be propagated by those who are involved in the deployment of these technologies, and who have presumably seen them shorn of their mythical aura in that process.

\section{Myths and Digital Technologies}

In The Digital Sublime: Myth, Power, and Cyberspace," Mosco argues that the discourse around new technologies may be understood as the creation and maintenance of a myth (Mosco 2004). Drawing on cultural studies and mythology, he suggests that myths are not lies, nor exaggerations. Rather, they are narratives founded on elements of reality. Myths reveal as much as they conceal, and focus the attention of the listener on specific points, hiding others. Thus, myths make a formidable contribution to shaping how people think about the object of the myth, which, in Mosco's examples, are cyberspace and digital technologies. Mosco's myths are what Donald Mackenzie, in referring to financial models, calls engines and not cameras: myths don't so much reflect what the objects they describe can do in the world, as they actively produce that world (Mackenzie 2006). For Mosco what is important is not whether myths are true or false, but whether they are living or dead. Since living myths have material consequences in shaping the world, theorizing their persistence (or fading) is crucial (Mosco 2004, 29). Mosco suggests that myths about technologies circulate in the early stages of the technology's development and 
deployment. By the time technologies become banal-and so taken for granted as to become invisible-myths about them cease. Furthermore, Mosco argues that, historically, the social impact of technologies has been the greatest after they have been deployed a long time; seldom have the "real powers" of new technologies been leveraged during the initial "myth-making" phase. Thus,

It was not when electricity was hailed for its ability to light up the streets, end crime, and bring peace and harmony to the world that its power was most profound. It was long after the numerous World's Fairs and Exhibitions that celebrated "the Great White Way" or lit up the sky with "Celestial Advertising" were over and electricity ceased to inspire rapture, ceased to fill popular fiction with a cornucopia of imagined blessings, that it began to change how people led their lives and organized their societies. (Mosco 2004, 19)

Digital technologies are now relatively commonplace in everyday lives, including in the Global South. Two applications of digital technologies are of particular interest to us: digital identity and mobile money. Compared to the examples that Mosco provides-where it took a long period for technologies to become banal-the uptake of these two digital technologies has proceeded rapidly. A range of governments, international funders, non-governmental agencies, and private start-ups have expressed support and been involved in deploying them in the Global South. These actors claim that such technologies will help usher in a new era of governance by eliminating corruption, improving efficiencies, and making a range of welfare and other services accessible to low-income populations.

In this paper, we draw on a combination of secondary research and primary, qualitative fieldwork carried out in India and Myanmar to examine whether the deployments of these technologies lived up to their mythology when they encountered local moral and political economies. The work on digital ID systems in India includes interview-based research carried out as part of a project on identities that the first author was associated with in 2016-17. The research team for this project talked with 150 respondents in urban, peri-urban and rural Delhi, Assam and Karnataka (Caribou Digital 2017; Srinivasan et al. 2018). In addition to this, the account builds on existing academic research and press coverage on the Aadhaar ID project. The analysis of mobile money is based on the second author's research among agricultural communities in Shan state, Myanmar in 2016, which included around 40 interviews and participant observation activities with farmers and small traders (Oreglia and Srinivasan 2017, 2019). In all cases, our examination of ground realities is augmented by an analysis of secondary material on how these projects were marketed and have evolved.

\section{Myths and/in Practice}

At least since the 2000s, there has been a significant emphasis on digital systems in the administration of welfare schemes and initiatives in the Global South, especially those related to financial inclusion. Besides the promise associated with the use of such systems globally, the use of digital systems in the Global South has additionally been presented as a means to "leapfrog" 
stages of development and catch up to countries of the Global North. Mobile money platforms and ID systems are extolled because (in theory) they allow their patrons to access financial information and services on personal mobile phones or other digital devices, in any place, at any time, and without the need for intermediaries. Both draw on and/or reinforce the twin myths of "death of distance" and "disintermediation." The findings we present here show, in fact, the continued importance of place, face-to-face communication, and intermediaries in the use of these platforms. However, following Mosco's claim that the significant characteristic of myths is not whether they mirror reality, but rather whether they are living or dead, we go on to understand why these myths live. Furthermore, we explore how the value placed on these myths has gone on to shape how face-to-face communication and intermediaries are valued within the digital identity and mobile money ecologies in development discourse and initiatives.

\section{Death of Distance/Place}

One of the founding myths associated with digital technologies is that place will cease to matter as digital technologies become ubiquitous; and that place-based constraints will fall away as people start to use these technologies. In the words of one of the mythmakers of cyberspace, "Information has replaced both propinquity and politics as the factor most likely to shape the flows of economic activity" (Ohmae 1995, 28). Recent claims build on this older myth: they suggest that the portability of new digital systems allows them to transcend geography or operate regardless of it. Digital identity systems capture this sentiment especially well. The inclusion of "a legal identity for all" by 2030 in the UN's Sustainable Development Goals has catapulted the provision of IDs as a priority in many countries, especially in the Global South. World Bank's recent Principles on Identification for Sustainable Development: Towards the Digital Age, which was endorsed by a variety of organizations, including the Gates Foundation, Asian and African Development Banks, various UN organizations, MasterCard, and GSMA, has further made digital identity platforms visible (World Bank 2018). Digital identity systems are now being deployed in many countries of the Global South by states and by private actors to supplement or, in some cases, supplant traditional identity systems.

Identity systems have, of course, been part of the fabric of every state and community for centuries. Making populations legible has been a key part of state-making globally and throughout history (Scott 1998). The granular reasons for a state to aim for legibility using identity systems and ID documents have been many (conscription in the military, taxation, administering welfare and governance, disciplining criminals) (Breckenridge 2014; Chottray and McConnell 2018; Finn et al. 2014; Scott 1998; Singha 2000; Sriraman 2018). Moreover, at certain key moments in a state's history, this need for legibility has peaked. Sriraman points to a few such key purposes and moments in the Indian case: the British Raj's desire to monitor those it identified as criminals_or entire communities it perceived as "criminal" populations-through

${ }^{3}$ For example, the World Economic Forum's Global IT report (2008-09) suggests that mobile phones reduce the role of "middlemen" (Dutta \& Mia, 2009, 60), while the G20 argued that mobile banking is significant for financial inclusion and by extension, for inclusive growth (G20 2010). 
the 1800s; the independent Indian state's need to manage a massive refugee population after the subcontinent's partition into two countries in 1947; and during a state-imposed Emergency in the 1970s, among others (Sriraman 2018). The state's tools and techniques to achieve legibility (even just the official ones) have been no less varied. They have included using fingerprints and other biometrics, as well as documents, such as birth certificates, passports, ration cards, and national ID cards (Breckenridge 2014; Chottray and McConnell 2018; Singha 2000).

Digital ID systems claim to be more efficient and effective than their (largely paperbased) predecessors. They also pervade more domains of people's everyday activities than previous systems and, in many cases, are amenable to being linked across these different domains. Most importantly, they are perceived to be portable in a way that earlier systems were not. Few ID systems embody this vision and hope better than India's controversial Unique ID (Aadhaar) project (Chaudhuri and Koenig 2018; Chaudhuri 2019; Johri and Srinivasan 2014; Nair 2018; Srinivasan and Johri 2013).* The government of India launched the project in 2009. In the decade since its inception, over 1.2 billion Aadhaar numbers-biometric-based 12-digit unique identification numbers-have been allotted to residents of India upon their enrolment. ${ }^{.}$Aadhaar enrolment involves the collection of demographic data (including name, date of birth or age, gender, and address, with mobile number and email ID as optional fields) and biometric data (ten fingerprints, two iris scans, and facial photograph) from individuals. ${ }^{6}$ Today, linking servicespecific identity cards to Aadhaar is mandatory for several services (such as availing welfare benefits under the National Employment Guarantee Scheme, or drawing food rations from the Public Distribution System or PDS). Furthermore, physical copies of Aadhaar cards are equally used as identity proofs, instead of or in addition to digital linking and biometric authentication.

Right from the start, Aadhaar has been widely covered by the international and Indian press, receiving accolades for its technological attributes and capacity--“"the World's biggest ID database" (BBC News 2012; Jayadevan 2012)--but also for its perceived outcomes, having variously been described as "A reform by numbers," (Economist 2012) a "game changing scheme," (Hindu 2009) a "project of national transformation," and even "the biggest social project on planet"(Parker 2012). The mythology of Aadhaar, in this way, is established much like the myths Mosco details, where positive effects were asserted without necessarily being backed by evidence. Since its inception, Aadhaar has been offered as a single-stop solution to attack, even "leapfrog," many ills. National security has often been offered as a reason, as have efficiency and stopping leakage in administering welfare schemes (Hindustan Times 2017). In the narrative crafted by supporters of the project, corruption would be phased out by reducing the discretion

\footnotetext{
"Aadhaar is described as a "foundational" ID system, and not a "functional" one. It merely authenticates identity and offers a platform. In order to use Aadhaar to obtain services, other systems, such as for social protection, need to be linked to Aadhaar.

${ }_{5}$ As of April 15, 2020, 1,257,490,859 Aadhaar numbers have been generated according to UIDAI. See https:/ / uidai.gov.in/aadhaar dashboard/india.php

"Enrolment details as documented on the official UIDAI website. See https://uidai.gov.in/myaadhaar/about-your-aadhaar.html

An Aadhaar card is mandatory in practice, if not required by law, for even more services.

" Nilekani admits, "I'm a big believer that if you build the right digital infrastructure then you can leapfrog," (Hindustan Times 2017). See also Economic Times (2010) and (2012).
} 
of human intermediaries in the welfare administration process, replacing it with the Aadhaar card and the unique fingerprints of welfare beneficiaries. A second goal was inclusion (Bhatia and Bhabha 2017), which involved setting up a system to issue ID cards to all, including those who previously did not have one, and thus expand the state's ability to extend benefits to a larger population.

A third objective of "portability" is of particular interest given our focus on the "end of geography" myth. Because Aadhaar was supposed to be a national identity infrastructure, i.e., Aadhaar numbers could be authenticated anywhere in the country, it was to make "identity portable like a mobile phone makes communication portable" (Sharma 2010). This idea was hailed because of its perceived benefits for internal migrants, who typically had difficulties claiming welfare benefits such as food rations from the state Public Distribution System outlets because they only had state-specific PDS IDs (called "ration cards") associated with their place of origin. They would now be able to avail themselves of benefits such as food rations anywhere in the country by linking their Aadhaar and ration cards. The national portability of the Aadhaar number would, thus, translate to portable material benefits (ibid). In practice, however, place continued to matter in many ways. For instance, the food distribution system had to have enough inventories in a specific place in order to provide rations to those wishing to use them by showing their Aadhaar-linked ration cards there, which posed a challenge in implementation (Khera 2011). Moreover, even where portability of ration cards has been shown to be useful (in Chhattisgarh, for example), researchers have found that the "portability" of benefits has mainly been used by people at ration shops within the same ward (Khera 2014). ${ }^{\circ 0}$ This is partially because ration cards are issued to households and food rations can only be drawn from one location in a given period (even if, with portability, that location may be different than the one closest to the address on the card). Typically, this would mean that migrants' families might continue to collect rations in their villages, with the urban migrant collecting their share during their regular visits to the village." In these ways, the particularities of place continue to matter in the working of the PDS ecosystem in practice.

Interestingly, one kind of portability that Aadhaar has actively resisted through its use of biometrics (and towards its goal of curbing fraud and leakage) has been the transfer of IDs to neighbors or others to collect ration on behalf of those unable to travel to ration shops for reasons

\footnotetext{
" "Our idea is to not just focus on development, but to bring about inclusive growth amongst our people," said the Chairperson of the United Progressive Alliance, which was the ruling alliance at the center between 2004-2014 (Byatnal 2010)

${ }^{10}$ Besides Chattisgarh, which used a system without Aadhaar, subsequent initiatives in other states have also attempted to achieve portability at state and national levels (Economic Times 2019). Here, too, the use of cards in a location other than the registered address was rare. For example, only $0.02 \%$ of 1.47 crore family ration cards in Karnataka in 2020 have collected rations from a ration shop that was not the closest to the registered address in 2020, according to the Food and Civil Supplies Department website (Hindu 2020).

"The ongoing COVID lockdown presents an extreme example of what happens when this arrangement breaks down and shows the continued importance of place. Migrants in cities have travelled back to their villages because they had no way to access rations in the city and their ration cards were with their families who needed and would regularly collect rations back in their village. This is despite ration card portability (Hindu 2020).
} 
of ill-health or disability (Chaudhuri 2019; Druze et al 2017). In our research on ID systems (which was not confined to Aadhaar) we had respondents who said they gave their ration card to a neighbor, saying "OK, today you get your ration with this...Next month I will use it for myself" (Caribou 2017, 26). They reasoned that since their neighbors' economic condition made them "feel sad," they would "let them have our ration" (ibid). Thus, where Aadhaar's focus was on ridding welfare schemes of corruption by eliminating all but the "deserving poor" from accessing welfare, "the poor" in a community knew each other and their changing economic circumstances. E.P. Thompson argues that economic transactions operate within a "moral economy," that is, "a consistent traditional view of social norms and obligations, of the proper economic functions of several parties within the community" (Thompson 1971)." It is this moral economy among the poor who use ration cards that undergirded their understanding of whom to perceive as "deserving" at certain moments; further, there was a sense of responsibility towards such individuals, accompanied by short or long-term reciprocity. While moral economies are not static, they are deep-rooted, and any change in the values and priorities they espouse is gradual. Understanding how these local moral economies work allows us to understand the politics of how specific goals and procedures become prioritized in any economic system (Sayer 2000), and how particular economic functions and transactions come to be accepted as just, unjust, legitimate, or illegitimate in that given system.

The use of multiple IDs associated with different places and addresses by our respondents also highlighted the continued significance they attached to place. Additionally, their words also helped explain why they perceived this practice as a just and legitimate way to handle the complexity of using a static ID to negotiate their dynamic needs (Caribou Digital 2017; Srinivasan et al. 2018). Migration and marriage (for women, in particular) came up as instances where respondents were interested in retaining their ID with their old address, even as they enrolled for one with their new address. A respondent who had migrated from a village to the city of Delhi, where he worked in a factory and was also a labor rights activist pointed out that:

I wasn't sure how long I would stay in Delhi and the Aadhaar card can be made only once for all over India...I had decided that I'll make a voter ID card of Delhi and the Aadhaar of the village....because we have land in the village also, so I might require an address proof [associated with that village]. (Caribou 2017, 33)

Nor was this respondent's case unique: he (and other migrants we met) noted that many migrants he worked with preferred retaining an ID from their village even after they got

${ }_{12}$ Thompson writes about England's transition to capitalism in the $18^{\text {in }}$ century. To explain the food riots that regularly erupted in this period, Thompson looks beyond "elementary economic stimuli" and scarcity of bread during this period. He argues that the riots took place only once commonly held ideas about the role of various actors in the bread economy (the state, farmers, millers, bakers, consumers, etc.) were violated by the newer forms of economic transactions taking root. Not every instance of bread scarcity resulted in riots, nor did the rioters always carry off bread without paying for it. Thompson shows how, time and again, those rioting for bread only took bread from those individuals and establishments who were commonly seen to be making unfair profits, rather than loot millers or bakers that they randomly picked. In many cases, rioters even left behind what was commonly considered a fair price for the bread they took. 
themselves a new ID that reflected their current address (Note: not all of these IDs were digital and many services required an ID with a local address on it.) Since migration seldom meant a severing of relationships with their place of origin, most migrants felt this need for multiple IDs in order to maintain their ties (and responsibilities) in multiple geographies. Marriage (and separation) proved to be another reason favoring multiple IDs, especially for women. Two female respondents in rural Karnataka explained their decisions to give up or retain their names on ration cards in their natal village upon their marriage and move to their husband's village. One respondent decided to have her name on both her parents' and husband's ration card (though this was legally problematic), saying she "didn't want to remove it [from the former]" (ibid). The one who had struck her name off her parents' ration card got divorced and moved to a city as a single mother. Her in-laws retained the ration card that had her name on it, which made it hard for her to receive rations in the city. People were, thus, using multiple IDs in order to maintain their connections (especially in the administrative sense) to different places; they were leveraging the place-based nature of these IDs to negotiate their life circumstances.

Finally, both in the PDS systems examined above and in other systems and regions, geography-specific technological and administrative challenges have plagued the deployment and use of Aadhaar in different regions despite UIDAI's vision "to empower residents of India with a unique identity and a digital platform to authenticate anytime, anywhere (UIDAI 2016). Aadhaar was built to "transcend geography" through the standardization of processes to set up Aadhaar enrolment agencies, and of enrolment and authentication procedures themselves across the country, However, it is local enrolment agents (ironically, introduced by Aadhaar) that have proved critical in understanding the physical and social infrastructural realities of a place and helping users navigate them (Chaudhuri 2019; Caribou 2017; Johri and Srinivasan 2014). Much like the example of neighbors who shared IDs, such intermediaries also leveraged the placebased local moral economy to make this "portable" ID work. While such "intermediaries" can and will exploit the resources and value they bring, this exploitation cannot be automatically assumed without an analysis of the social relations within which this mediation is embedded, or the perceived value of intermediaries dismissed, as we will discuss in the next section.

\section{Disintermediation}

Another myth connected with digital technologies is that they will do away with the need for intermediaries. While disintermediation has long been a goal for digital technologies around the world (Brown and Duguid 2000), the casting out of intermediaries has been a key goal of the introduction of digital technologies in the Global South. Efforts at financial inclusion in the Global South, in particular, often express concern with the number of people who are outside of formal banking networks ("unbanked") or rely on intermediaries. The attraction of digital technologies in the financial sector is their potential to allow those who cannot physically reach a bank or other financial services to leverage technologies such as mobile phones or mobile money platforms to access money, bank accounts, or insurance remotely, and without a need for intermediaries (Demirgüç-Kunt et al. 2017). The myth-making starts by conflating access to formal 
financial services with access to any financial service at all; it continues by assuming that family savings or informal money lenders are inferior and possibly expensive alternatives: "Fewer than 20 people out of 100 have access to formal financial services, with most people relying on family savings or costly alternatives such as informal money lenders" (Duflos et al. 2013). The myth is strengthened and propagated by high-profile champions, the mythmakers described by Mosco, who push the narrative to describe a utopian future where digital technologies solve problems that have long been intractable.

In Myanmar, mobile money entrepreneurs, NGOs, and the State push digital technologies as tools necessary to achieve financial inclusion. "The majority of our population is either unbanked or under-banked, and many unfortunately are "un-bankable" by traditional methods... Mobile money changes all that and makes financial services available to everyone. All they need is a mobile phone and an ID," in the words of a mobile money entrepreneur (Trautwein 2016). The country's Financial Inclusion Roadmap 2014-2020, published by MAP: Making Access Possible, is a partnership of international organizations that work with the government and other stakeholders to ensure an "inclusive, holistic process" for financial inclusion; it identifies mobile phone saving wallets as a tool for "mobilizing savings" (MAP 2014). This was published at a time when mobile phone penetration in the country was very low, due to the restrictive policies regarding media and communication of the military regime that had been in power until 2011. The potential of mobile wallets and mobile money was still entirely theoretical, given that the uptake of mobiles started in earnest only in 2015, and mobile money wasn't introduced until 2016. In 2019, the country had five mobile money providers ${ }^{13}$ and a market that relies heavily on agents to carry out operations: the earliest and most widespread operator, WaveMoney, alone has a network of 55,000 agents (Staehelin 2019). Mobile money is used primarily for internal remittances, and while this has eaten into the market share of informal money transfer providers, it has not increased significantly the number of people with access to formal financial systems.

The push for financial inclusion mostly ignores the actual workings of unofficial networks of money circulation, borrowing and lending, or treats the middlemen involved as expensive, inefficient, potentially exploitative, and, in recent years, as vehicles for financing terrorism (Baig 2017). Economists understand that bringing the unbanked into the official financial system has many advantages to the economy, but the popular impression is that the unbanked do not have any way to access loans or preserve savings or can do so only under punitive conditions. The mythmakers help cast technology as the simple solution to very complex circumstances. Myanmar is still in political and economic transition, and trust in individuals is central to how important parts of the economy, in particular agriculture, work. The long history of demonetization carried out by the military dictatorship (1962-2010), at times without conversion, left a legacy of distrust towards government institutions, and of robust systems to bypass them, especially in the financial sector. Reforms that began in the early 2010s are opening up the banking sector to private and some foreign operators, and new banks have

${ }_{13}$ See the regularly updated list on the Central Bank of Myanmar website, https:/ / www.cbm.gov.mm/ content/2653 
opened branches in small towns like the one where we carried out field work. But the atmosphere of distrust towards any institutional intervention in the economy continues. The real challenge for formal financial institutions is not to reach clients, but rather to be trusted by them. According to surveys from the Global Findex Database (World Bank 2018), in 2017 26\% of the population had a bank account, compared to $23 \%$ in 2014; surprisingly, the percentage of people who save at a financial institution decreased from 13\% in 2014 to $8 \%$ in 2017, while the percentage of people saving through an informal savings club has gone from $6 \%$ to $8 \%$. Slightly more people are borrowing from financial institutions (16\% in 2014, 19\% in 2017), but they are surpassed by the percentage of people borrowing from family or friends (a steady 22\%), who are also described as the main source of emergency funds. The "unbanked" are in fact enmeshed in a trusted informal system that fulfills at least some of their needs: family, friends, and informal intermediaries are still key to financial transactions, and the fact that mobile phones, mobile money, and some forms of digital banking are now widespread has not changed people's use of the informal sector in any meaningful way.

The value that informal intermediaries are providing is partly economic, partly social (Oreglia and Srinivasan 2019). In market towns across Shan state farmers and traders hold daily and seasonal markets to sell to locals and traders that then export to Mandalay and the rest of the country, or to foreign countries, especially China. The markets are characterized by cash transactions for retail purchases, but, beyond that, complex credit relations extend geographically and through time. Because of our field work area's geographical location on the main road between northern Myanmar and China, commerce has always been very active, and a variety of unofficial, sometimes illegal, and yet highly developed means of transferring money and extending credit have always existed. Transport companies, which operate buses that transport people and goods between local towns, have been and still are a common way to move money from one place to the other. Retail market sellers in the town's wet market described traveling to a wholesale market famous for the good they wanted to sell, e.g. Pyin Oo Lwin for flowers and strawberries, Lashio or Muse in the north for apples and pears, or Mandalay for rice and other produce coming from the south of the country. There they found a wholesaler they trusted (typically someone recommended by another seller at their market, and often someone of their same ethnicity, or that they could trust through ethnic ties back home), who agreed to send them the product on the bus and be paid by the bus company. Once back to town, they placed their order with the bus company driver, who passed it on to the wholesaler, who then sent the produce on the bus. The buyer paid on receipt of goods, or once a month, depending on what kind of relation they had with the seller, to the bus company." When asked what recourse people had when there were problems with money, e.g., the right amount was not delivered or paid out or paid in time, more than one interviewee said that since all the parties involved lived in town or had relatives there, things would get settled one way or the other.

${ }^{14}$ People commonly refer to this as giving the money to the bus driver to bring to the wholesaler, but in fact the money travels rarely: all bus companies have a series of correspondents in the different towns they serve, which function as a clearing house for all the money transfers. 
Small tea traders that extend credit or give loans to tea farmers provide another example of unofficial financial networks. A tea broker based in the town, who visits tea growers in remote villages, explains it thus:

Before the April harvest, we go to the villages and give farmers rice, clothes, etc. Farmers don't have money then, so they borrow money or rice or other things. Then when they harvest the tea, they have to give money back to us, and so they sell us the tea.

The quote here is representative of the role that traders play in farming communities in many countries of the Global South. However, traders are often represented only as taking advantage of poor farmers in need of credit, who may be ignorant and unaware of prices in different markets, and not mobile, so unable to travel to other markets that might offer better prices. These traders/loan sharks are precisely the people that the myth of disintermediation promises to eliminate. But a different perspective on traders such as the one cited above is that they have long-established relations with the farmers from whom they buy, and they are more trusted than large urban traders who are unlikely to extend credit to such small producers, as they are too small and unproductive to matter. As we saw in the Indian case, the moral economy-which, it is worth underlining, is not necessarily an economy characterized by morality, but rather a system where participants agree on values beyond monetary ones-exerts itself through the web of family and ethnic relationships that contribute to assess right and wrong. In this case, a complex set of economic and non-economic factors dictates who is accepted as a wholesaler: often, wholesalers are chosen not according to the prices or the payment conditions they offer, but rather based on ethnicity, which is considered code for trustworthiness. Traders are chosen on the basis of what they can offer beyond the best prices at harvest, in an ongoing relationship that is partly economic, partly social. As Roitman argues when writing about the politics of informal markets in sub-Saharan Africa: “(...) social formations (...) determine which choices and alternatives within the productive process are themselves legitimate" (Roitman 1990, 676). The recent history of Myanmar has resulted in fraught relations between the Burmese majority and ethnic minorities, and tensions among different religions. Reverting to known ethnic ties is often a legitimate way to establish trust, but also to avoid dealing with other ethnicities. As in the Indian case above, we are not romanticizing these ethnic ties: exploitation exists within the same ethnicity, and traders do business with farmers and other traders across ethnicities. The existence of such ties, however, explains behaviors that cannot be justified from the viewpoint of financial interest alone.

From these examples, we can see how the myth of disintermediation hides the resources and values that animate "unbanked" communities, which get obscured by the narrative of exclusion and then the promise of digitally-mediated inclusion. Trading relations in these communities work along networks and with intermediaries who are seen to provide value (and not just due to lack of other options) in the moral economy within which the community operates. Transactions are still visibly embedded in a moral economy where intermediaries are not an obstacle between farmers and their financial wellbeing. Instead, they are the people who 
play a "proper economic function... within the community" (Thompson 1971). This would include traders extending credit (and food and clothes) to farmers before the harvest is done, without knowing how the harvest and subsequent market prices will turn out. They also provide a service to all those farmers who do not have the resources or an interest to engage with town markets and with a world where they are often looked down upon: through their service, traders allow farmers an opportunity to participate in this larger economy. Even as trade is becoming less and less profitable for small traders who act as intermediaries, these traders continue to play their role in both the community and in small-town trade.

As we also saw above, intermediaries have been introduced by mobile money companies themselves once they discovered why mobile money agents might prove indispensable in the functioning of successful mobile money platforms like m-Pesa in Kenya (Mas and Morawczynski 2009). The myth of disintermediation, thus, is compromised by the need for new intermediaries, albeit of a new kind. The moral economy of mistrust towards the state, and trust in systems that have been reliable during extremely unreliable times, makes informal financial systems persistent despite the myth that digital money can let people "leapfrog" their historical legacies.

\section{Why Myths Persist}

Despite the clash between the grand narratives and their local deployment, the myth-making surrounding them has not faded. Our goal here is not to examine the frequency with which claims hold or fail (or to make a counter claim that they always fail), but to examine why the mythology around digital technologies survives in light of a fair number of documented failures. While the previous section suggested that on the ground Aadhaar continues to be place-based and its targeted users continue to implicitly/explicitly value place, the myth of portability, as well as others to do with enhancing national security, corruption eradication, and inclusion, live on. In fact, our conversations with interviewees on identity sometimes showed an acceptance of these myths, especially around security, without necessarily being supported by concrete incidents from their own lives, those of their acquaintances, or even incidents they knew about indirectly.15 Thus, a lack of evidence to support these myths does not appear to have led to their perishing. Nor have the myths subsided in the face of doubts being raised about the cost-savings Aadhaar claims to have brought about, critiques of its constitutionality, its exclusion of beneficiaries from state welfare schemes, and its privacy implications."t

To the extent that myths have consequences and shape action, it is important to examine why the mythology around digital technologies has survived this long despite their less-thanimpressive rapid spread and near ubiquity. The breadth and diversity of constantly evolving components under the umbrella of cyberspace or digital technologies partially explains the

\footnotetext{
${ }_{15}$ We heard, in our interviews in Delhi, for instance, that Aadhaar would be helpful in "catching criminals" and terrorists (Srinivasan et al. 2018).

${ }^{16}$ For more on the range of critiques by activists and academics that have been in the news, see Bhatia (2018); Hindu (2011); Jayaram (2017); Khera (2017); Mukherjee (2011); Ramakumar (2011) and Ramanathan (2017). Aadhaar has been taken to court on these grounds and the court case was covered extensively in the press.
} 
persistence of myth-making around them. This evolution allows each new app, service, or platform to be presented as a new iteration of the original myth that it is both based on and deviates from. We leverage both "the grand narrative" of political economy and the "militant particularism" arising from grounding these myths in local realities (Mosco 2004, 142) to offer two more reasons that explain the persistence of mythmaking in the realms and geographies we have been discussing: the integration of these myths into existing, country-specific projects of state and future-making, and the political economy of technology deployment.

\section{Techno-optimistic Futures (and Pasts)}

Technologies spanning railways, telegraph, and plumbing systems acted as the "tools of empire" and undergirded the British rule of India (Bayly 2000; Headrick 1981; Headrick 1988). The link between technology and state-making only made further inroads after India's independence. Technology also became strongly linked to a nationalist agenda at the time (Sukumar 2019). Tracing the political history of technology in India, Sukumar argues that "Over decades, technology came to signify many things to India's political class: an agent of disruption for some, a symbol of modernity and an object of desire for others" (Ibid). The mythology of Aadhaar is but the latest chapter in this trajectory to establish India as a builder, leader, and embracer of modern technology. In the Myanmar case, the government, international and local NGOs, and entrepreneurs constantly emphasize the potential of digital technologies to leapfrog stages of development and make up for years of missed development.

To understand how the mythology of digital systems is built on longer histories and understandings of nationhood, we turn our attention to the mythmakers associated with digital identity systems and digital financial services in India and Myanmar. Mosco pays particular attention to the mythmakers who constructed the myths around cyberspace, individuals like Nicholas Negroponte and Bill Gates, who acted as "bricoleurs" merging "the heroic narrative with didactic effect" (Mosco 2004, 36). Historically, technocrats have played a central, "even outsized," role in nation-building in India and can be counted among its most prominent mythmakers (Sukumar 2019). Aadhaar has been no different: Nandan Nilekani, co-founder of the enormously successful software services firm Infosys, a successful entrepreneur and a veteran of India's IT sector, proved to be an influential mythmaker for Aadhaar. India's "ID man" (Parker 2011) first brought up the idea of a Unique ID for every Indian resident in his book Imagining India. Later, as the chairperson of Unique Identity Authority of India (UIDAI), he was the public face of Aadhaar for several years, together with political leaders of the ruling alliance (the Congress-led United Progressive Alliance) when the platform was launched in 2009 and others since. Nilekani was among the first to suggest that the goals of physical infrastructure were now passé for India; it was virtual infrastructure that would count towards achieving the nation's developmental vision. Thus, "Roti, kapada, makaan" (food, clothing, shelter) had given way to "bijli, sadak, pani" (electricity, roads, water), and these would now yield to "all virtual thingsit's about UID (unique identification) number, mobile phone and bank account"(Hindu 2010). Prime Minister Modi's more recent enthusiasm for Aadhaar and his "JAM" (Jan Dhan bank 
accounts, Aadhaar, Mobile) style of governance appears to further build on Nilekani's vision and narrative for Aadhaar (NDTV India 2015). Nilekani also described Aadhar as "the biggest anticorruption platform in the world" (Indian Express 2014), an association that continues to animate conversations around Aadhaar's role in stopping fraud and leakage from the disbursement of welfare benefits. Many other individuals and organizations are also active as mythmakers, and their narratives are variations of Nilekani and PM Modi's: that digital technology will create a different, better future, with a more innovative and less corrupt economy and society. Furthermore, the aspirations connected to Aadhaar or digital identity systems are no longer solely domestic. With Aadhaar, India is now being perceived as a global leader in designing and deploying digital identity systems (Sharma 2016). In this way, and for all its focus on disruption and novelty, India's Aadhaar narrative actually builds on the country's long-standing ambitions and aspirations vis-à-vis technology.

While Myanmar does not have such high-profile "digital mythmakers," the mantra of social and economic transformation through digital platforms is ubiquitous. The digital is offered as the tool that will allow the country to overcome its lack of basic infrastructure and the "backward" state of the economy that are the result of the isolation of the military dictatorship years: to this day, the country is on the UN list of Least Developed Countries, and among the last in any global index of digital innovation, skills, and business use (Digital Economy Development Committee 2019). "Leapfrogging" is the keyword used to erase decades of lost development: "Myanmar is developing better connectivity, mobile solutions and e-commerce platforms such that it is already leapfrogging more developed countries" "; "Fintech in Myanmar: Leapfrogging to mobile money?" "s; "Myanmar is a late bloomer on the digital front so we will leapfrog other economies with available technology. Our country has good potential to ride the digital wave." They are all indicative of the vision for a bright digital future that should have been unleashed with the opening of the mobile operators' market in 2014 and the subsequent widespread adoption of smartphones across the country. But, so far, the revolution has left the basic structure of the economy intact, as the country continues to remain dependent on agriculture, extractive industries, and low value-added manufacturing. The very optimistic projections of the Myanmar Digital Economy Roadmap expect 300,000 people to be employed in the digital economy by 2025; they also acknowledge that, as of 2019, that number is zero.

It is worth noting here that our examples, like Mosco's, indicate that an important component of mythmaking involves destroying what came before. In our examples, the myth of the digital country serves not only to reassert the country's standing in the global scene as technological innovator (India) or early adopter (Myanmar), and to negate earlier subordinate experiences. It also, in parallel, vilifies existing networks and relations with intermediaries, and

\footnotetext{
${ }_{17}$ Quote from UThaung Tin, Vice Chair of Union of Myanmar Federation Chamber of Commerce and Industry (Ko Ko 2019a).

1s From Accion, an international NGO active in fintech and financial inclusion, in 2017, https:/ / www.accion.org/ fintech-in-myanmar-leapfrogging-to-mobile-money

19 Quote from Mya Moe Aung, member of the Digital Economy Development Committee (Ko Ko2019b).
} 
material forms of money circulation in the service of "Faceless, Placeless, and Cashless" (Baig 2017).

Finally, the framing of the social circumstances at a historical conjecture as a "crisis" for the nation or a community might also facilitate the sustenance and acceptance of a myth. ${ }^{20}$ Elsewhere, Nair (2018) has argued that Aadhaar-especially its anti-corruption and national security framings-has fueled imaginaries about the "common, culpable man," the need for policing, and the channeling of national resources to "illegal" immigrants. Building on this, we argue that the mere framing of Aadhaar, or mobile money, as a solution to a nation in "crisis" (because of corruption, terrorism, crime, unbanked populations) "became a device for understanding how to act effectively in situations [that otherwise] belie... a sense of possibility" (Roitman 2012). Thus, while Aadhaar or mobile money platform's mythologies-conceptually and in practice-might not always have aligned with the "commonly held beliefs about the rights and responsibilities of various economic actors" in a community, we offer that their framing in terms of a crisis prepared the ground for these mythologies to marginally reshape beliefs about the (economic and political) rights various actors (in our cases, this would especially include intermediaries) have (Thompson 1971).

\section{The Political Economy of Sustaining Myths}

If a deep embedding in narratives of nationalism, state-making, and crisis-aversion offer one set of reasons for the persistence of digital mythologies, the political economy of digital technologies and their creators offers another. Aadhaar, in particular, is designed as a platform on which other private companies can build their technologies. An entire ecology, therefore, depends on Aadhaar working and on people enrolling in and linking Aadhaar in India today. The collaborative arrangement of state, corporations and applicable technical standards that are involved in identity management and new identity card systems has been labeled a "card cartel" (Colin and Lyon 2008; Bhatia and Bhabha 2017). While deeply embedded in state infrastructure, Aadhaar has relied on external contracts and partnerships with individuals, corporations, and other organizations around the globe for its biometric scanners, the development of its enrolment system, the setting up of enrolment stations across India, and various other needs (Thaker 2018). Since Aadhaar is at the core of visions ranging from financial inclusion to improved social protection schemes, this ecology of players also spans various sectors. For all of these players, the continuation of Aadhaar-based systems is critical for their operations: the fierce lobbying by the fintech sector against the 2018 Indian Supreme Court Judgment restricting private players from requiring Aadhaar as a form of authentication from their customers is just one example of the significance of Aadhaar for businesses (Bhakta 2018; Ganguly 2018). Thus, in addition to the mythmakers we saw earlier, these players also have significant stakes in sustaining the Aadhaar mythology (Economic Times 2018; Ganguly 2018). 
In Myanmar, the digital revolution has so far resulted in the creation of a supply-driven eco-system of start-ups and investors in the digital sector, especially in fintech. Alongside digital money providers fully regulated by the Central Bank, such as Wave Money, which we mentioned earlier, there are opportunistic businesses, or companies that operate without a license and without protections for clients or agents, as they occupy market shares and take a "build it and they will come" approach that transfers most of the risk to end users." In 2018, there were 11 mobile wallet and four digital payments operators and start-ups ( $\mathrm{Ng} 2018$ ), and in 2020, a private sector development program supported by the UK Government organized a FinTech Challenge Myanmar day to pitch fintech solutions in e-identity, digital and financial literacy, digital remittances and finance. ${ }^{2}$ While internal remittances are one of the areas where mobile money has made a difference, it is still extremely difficult to send money to the country from abroad, and, as seen above with the Global Findex Survey, behaviors on the ground have not changed much. The next frontier of the political economy of digital technologies has already been identified, however: "Sending Money Home to Myanmar Can Be Cheaper and Less Illegal with Blockchain." ${ }^{23}$

\section{Conclusions}

Our challenges to the myths of digital ID and mobile money are not new. Our contribution in this paper is an examination of why those myths are still made and endorsed, despite research and experiences that contradict at least some of them and have shown how they play out differently in practice. The World Development Report 2016, titled Digital Dividends, hardly questioned many of the claims associated with the introduction of digital technologies. The UNDP'S Human Development Report from the same year cites digital implementations in the Global South as a string of successes, without ever mentioning the abundant counter-examples of failures. ${ }^{2 *}$ Meanwhile, initiatives carried out by several national governments and a range of development agencies continue to treat digital technologies as silver bullets that can help communities leapfrog the traditional consequences of limited access to capital and infrastructure, or weak institutions. What makes these claims possible?

\footnotetext{
${ }^{21}$ For example, OK Dollar operated without a license from the Central Bank for more than a year, before being granted one "to expand financial inclusion in the country" but without any evidence it did so. In fact, its terms and conditions remained in only English for a long time, and it did not meet the financial regulator's requirements even as it continued its operations. See https:/ / frontiermyanmar.net/en/centralbank-issues-licence-to-ok-dollar-but-no-change-to-fine-print; https: / / consultmyanmar.com / 2019/02/21/bursting-the-red-balloon/ ${ }_{22}$ See http://www.danafacility.com/fintech-challenge-myanmar-2020-to-drive-financial-inclusion/(last accessed on 20 April 2020)

${ }^{23}$ https: / / fintechnews.sg/29948/ remittance/blockchain-myanmar-thailand-everex /

${ }_{24}$ "Mobile phones and mobile Internet services offer many new opportunities for access to dynamic price information (as in Niger), productivity gains (as in Morocco), job creation in technology-based industries and labor-market services. They have helped poor female entrepreneurs through marketing information (as in Bangladesh) and contributed to the financial inclusion of poor people through mobile banking (as in Kenya)" ( UNDP 2016:40-41).
} 
Above we showed how local moral economies can provide insightful explanations for the persistence of behaviors that myth-makers identify as deviant and that they envision digital technologies rectifying. The values desired by those who make policy on technology deployment (the equivalence of digital and face-to-face communication; the lack of value attached to geography, ethnicity, or place; the always-exploitative middleman) might not match the moral underpinnings of the economic transactions undertaken by their targeted populations. But since the target populations are seldom participants in the making of policies for their communities, this mismatch need not fundamentally affect the dominance of certain generalized myths that come to be seen, over time, in the broader population as the values and priorities desirable for an economy. We suggest that, far from being an automatic process where the mythology around technology just naturally or automatically fades, which myths fade and which blossom is actively shaped by specific histories of state-making and nationalism, and the larger political economy of technology design. In other words, myth-making is also a strategy deployed by states and economic forces to create their own narratives and markets.

Myths continue to shape the world in concrete ways. Technology deployments might actively design "out" the part played by intermediaries, or by face-to-face interactions, assuming that they add no value. It is with an eye to rethink such assumptions and their implications that we need to continue to examine the relationship between myths about the developmental implications of digital technologies, and the moral and political economies in relation to which these are fashioned, maintained, and put to use.

\section{Author Biography}

Janaki Srinivasan is Assistant Professor at the International Institute for Information Technology, Bangalore and an affiliate of the Institute's Centre for Information Technology and Public Policy (CITAPP). She studies the political economy of information technology-based development in India using ethnographic and archival research.

\section{Author Biography}

Elisa Oreglia is a lecturer in Global Digital Cultures in the Department of Digital Humanities at King's College London. She studies the use of digital technologies among different communities in Asia, with a focus on China and Southeast Asia.

\section{Acknowledgements}

The authors would like to thank the Institute for Money Technology and Financial Inclusion, University of California, Irvine, and Caribou Digital for supporting their research. This paper benefited greatly from being presented at the Techno-Optimism Within and Beyond Silicon Valley conference held at the University of California Berkeley Center for Science, Technology, Medicine \& Society in October 2018. The authors would like to express their appreciation to the organizers 
and participants of this conference, especially Morgan Ames. Special thanks also to their discussant and co-panelists at the conference: Sreela Sarkar, Cindy Lin, Joseph Satish and Morgan Ames, who each provided detailed reviews on the paper draft and helped significantly reframe it. Finally, the authors would like to thank the anonymous reviewers who gave valuable comments on their ESTS submission.

\section{References}

Adas, Michael. 1990. Machines as the Measure of Men: Science, Technology, and Ideologies of Western Dominance. Cornell University Press.

Baig, Noman. 2017. Branchless Banking: Integrating Pakistan's Poor into the Global Financial Circuit. Institute for Money Technology and Financial Inclusion (IMTFI) Final Report. https:// www.imtfi.uci.edu/files/articles/2017/Final_Report_Baig_IMTFI2017_FINAL.p $\underline{\mathrm{df}}$

Bayly, C. A. 2000. Empire and Information: Intelligence Gathering and Social Communication in India, 1780-1870. Cambridge Studies in Indian History and Society. Cambridge University Press.

BBC News. 2010. “India to compile 'world's biggest' ID database," Sep 29, 2010. https://www.bbc.com/news/world-south-asia-11433541

Bhakta, Pratik. 2018. "India's fintech companies struggle for an alternative to Aadhaar." The Economic Times, Dec 21, 2018. https://economictimes.indiatimes.com/smallbiz/startups / features/indias-fintech-companies-struggle-for-an-alternative-toaadhaar/articleshow / 67186586.cms

Bhatia, A. and Bhabha, J. 2017. India's Aadhaar scheme and the promise of inclusive social protection. Oxford Development Studies, 45(1), 64-79.

Bhatia, Rahul. 2018." How India's Welfare Revolution Is Starving Citizens." The New Yorker, May 16, 2018. https:/ / www.newyorker.com/news/dispatch/how-indias-welfare-revolutionis-starving-citizens

Breckenridge, Keith. 2014. Biometric State: The Global Politics of Identification and Surveillance in South Africa. Cambridge: Cambridge University Press.

Brown, John Seely and Paul Duguid. 2000. The Social life of Information. Harvard Business Review Press.

Byatnal, Amruta. 2010. "Tembhli Becomes First Aadhar Village in India." The Hindu, Sept. 29, 2010. https://www.thehindu.com/news/national/Tembhli-becomes-first-Aadharvillage-in-India/article13673162.ece

Caribou Digital. 2017. Identities: New practices in a connected age. UK: Caribou Digital Publishing.

Chaudhuri, Bidisha and Lion König. 2018. "The Aadhaar scheme: a cornerstone of a new citizenship regime in India?" Contemporary South Asia, 26 (2), 127-142

Chaudhuri, Bidisha. 2019. "Paradoxes of Intermediation in Aadhaar: Human Making of a Digital Infrastructure." In Ursula Rao and Vijayanka Nair (eds.) Special Issue "Aadhaar: Governing India with Biometrics." Journal of South Asian Studies. 
Chhotray, Vasudha and Fiona McConnell. 2018. "Certifications of citizenship: the history, politics and materiality of identity documents in South Asian states and diasporas." Contemporary South Asia, $26 \quad$ (2), 111-126 Demirgüç-Kunt, Asli; Klapper, Leora; Singer, Dorothe; Ansar, Saniya and Jake Hess. 2018. The Global Findex Database 2017: Measuring Financial Inclusion and the Fintech Revolution. World Bank Group.

Digital Economy Development Committee. 2019. Myanmar Digital Economy Roadmap. https: / / myanmar.gov.mm/ documents / 20143/9096339/2019-0207+DEDC+RoadMap+for+Websites.pdf (last accessed 26 April 2020)

Drèze, Jean, Nazar Khalid, and Anmol Somanchi. 2017. "Aadhaar and Food Security in Jharkhand, Pain Without Gain?" Economic and Political Weekly, 52 (50).

Duflos, Eric, Paul Luchtenburg, Li Ren, and Li Yan Chen. 2013. Microfinance in Myanmar Sector Assessment. CGAP and International Finance Corporation, World Bank Group.

Dutta, S. and Mia, I. 2009. Global Information Technology Report 2008-2009. World Economic Forum. Economic Times. 2010. "Aadhar to Act as an Instrument of Social Inclusion: Nilekani." Dec 2, 2010. https:/ / economictimes.indiatimes.com/news/company/corporatetrends / aadhar-to-act-as-an-instrument-of-social-inclusionnilekani/articleshow / 7030565.cms?from $=\mathrm{mdr}$

Economic Times. 2012. The, "Aadhaar card would cut out bogus beneficiaries: Prithviraj Chavan." Aug 13, 2012. https://economictimes.indiatimes.com/news/politics-andnation/aadhaar-card-would-cut-out-bogus-beneficiaries-prithvirajchavan/articleshow/15481225.cms

Economist. 2012. "India's UID Scheme: Reform by Numbers." January 14, 2012. https: / / www.economist.com/asia/2012/01/14/reform-by-numbers

Findex, http: / / datatopics.worldbank.org/financialinclusion/country/myanmar

Finn, Megan, Janaki Srinivasan, and Rajesh Veeraraghavan. 2014. "Seeing with Paper: Government Documents and Material Participation." In IEEE Proceedings of the 47th Hawaii International Conference on System Sciences (HICSS), Hawaii.

G20. 2010. "G20 Principles for Innovative Financial Inclusion." G20, http:/ / www.gpfi.org/ knowledge-bank/ publications?page=1

Ganguly, Shreya. 2018."Fintech Companies Write To Govt Seeking Inclusion In Aadhaar Amendment." Inc42, 19 Dec 2018. https://inc42.com/buzz/fintech-companies-write-togovt-seeking-inclusion-in-aadhaar-amendment/

Gutierrez, Eva and Sandeep Singh. 2013. What Regulatory Frameworks are More Conducive to Mobile Banking? Empirical Evidence from Findex Data. World Bank Policy Research Working Paper No 6652. http: / / ssrn.com/abstract=2338858.

Headrick, Daniel R. 1988. The Tools of Empire: Technology and European Imperialism in the Nineteenth Century. Oxford University Press, USA.

Headrick, Daniel R. 1988. The Tentacles of Progress: Technology Transfer in the Age of Imperialism, 1850-1940. Oxford University Press, USA. 
Hindu. 2009. "A Game Changing Scheme." Nov 12, 2009. https:// www.thehindu.com/opinion/editorial/A-game-changingscheme/article16891727.ece

Hindu. 2010. "Slogan of 'Bijli, Sadak, Pani is Passe': Nilekani." Feb 14, 2010. https: / / www.thehindu.com/news/national/Slogan-of-bijli-sadak-pani-is-passeNilekani/article16814475.ece

Hindu. 2011. “Aadhaar Bound to Fail: Aruna Roy.” Sep 5, 2011.

Hindustan Times. 2017. “Aadhaar helped government save $\$ 9$ billion: Nandan Nilekani.” Oct 13, 2017. https://www.hindustantimes.com/business-news/aadhaar-helped-governmentsave-9-billion-nandan-nilekani/story-7dPISNcEZJsAhUdBAZSshP.html

Indian Express. 2014. "Aadhaar will help combat corruption, says Nandan Nilekani” January 13, 2014, https://indianexpress.com/article/india/politics/aadhaar-will-help-combatcorruption-says-nandan-nilekani/

Jayadevan, P.K. 2012. "UID: Due to the technology challenges of speed and scale, Aadhaar is an object of attention," The Economic Times, Feb. 7, 2012. https: / / economictimes.indiatimes.com/tech/ites/uid-due-to-the-technology-challengesof-speed-and-scale-aadhaar-is-an-object-of-attention/articleshow/11784861.cms

Jayaram, Malavika. 2017. "Aadhaar debate: Privacy is not an elitist concern-It's the only way to secure equality." Scroll, Aug 15, 2017. https://scroll.in/article/748043/aadhaar-debateprivacy-is-not-an-elitist-concern-its-the-only-way-to-secure-equality

Johri, Aditya and Janaki Srinivasan. 2014. "Aligning with Data: Populating the 'Unique Identity' Infrastructure in India." In ACM Proceedings of the Conference on Computer Supported Cooperative Work (CSCW), Baltimore.

Katiyar, Prerna. 2019. "One nation, one ration card: Inside food ministry's ambitious scheme to make ration cards portable." The Economic Times, November 17, 2019. https: / / economictimes.indiatimes.com/news/ economy/ policy/one-nation-one-rationcard-inside-food-ministrys-ambitious-scheme-to-make-ration-cardsportable/articleshow / 72089023.cms?from $=\mathrm{mdr}$

Khera, Reetika. 2011. "The UID Project and Social Welfare." Economic and Political Weekly, Vol. 46, No. 9.

Khera, Reetika. 2014. “UID project: Does Evidence Matter?" Yojana, A Development Monthly. July: 30-33

Khera, Reetika. 2017. "The different ways in which Aadhaar infringes on privacy." The Wire, Jul 19, 2017. https: / / thewire.in / featured / privacy-aadhaar-supreme-court

Ko Ko, Thiha. 2019a, "Opportunities available to digitise manufacturing, agriculture in Industry 4.0." Myanmar Times, 26 May 2019 https://www.mmtimes.com/news/opportunitiesavailable-digitise-manufacturing-agriculture-industry-40.html

Ko Ko, Thiha. 2019. "Govt draft roadmap to develop and support digital economy in Myanmar." Myanmar Times, 14 Apr 2019. https://www.mmtimes.com/news/govt-draft-roadmapdevelop-and-support-digital-economy-myanmar.html 
MAP. 2014. Myanmar: Financial Inclusion Roadmap 2014-2020. https://www.liftfund.org/ sites/liftfund.org/files/publication/UNCDF_myanmar_fi_roadmap_3_Apr_2015.pdf

Mas, I. and O. Morawczynski. 2009. Designing mobile money services lessons from M-PESA. Innovations: Technology, Governance, Globalization, 4(2), 77-91.

Mosco, Vincent. 2005. The Digital Sublime: Myth, Power, and Cyberspace. MIT Press.

Mukherjee, Arindam. 2011. "Aadhar, A Few Basic Issues." Outlook, Dec 5, 2011.

Nair, Vijayanka. 2018. "An Eye for an I: Recording Biometrics and Reconsidering Identity in Postcolonial India." Contemporary South Asia 26 (2), 143-156.

NDTV India. 2015. "PM Modi Outlines JAM Initiative." Sep 28, 2015. https: / / www.ndtv.com/india-news/ pm-modi-outlines-jam-initiative-1223711

$\mathrm{Ng}$, Royce. 2018. Myanmar Fintech Startup Report. Fintech Singapore, https: / / fintechnews.sg/fintech-myanmar-startups / (last accessed on 20 April 2020)

Nye, David E. 1996. American Technological Sublime. MIT Press.

Ohmae, Kenichi. 1995. The end of the nation state: The rise of regional economies. Simon and Schuster.

Oreglia, Elisa and Janaki Srinivasan. 2017. Intermediaries, Cash Economies, and Technological Change in Myanmar and India. Institute for Money Technology and Financial Inclusion (IMTFI) Final Report. https: / / www.imtfi.uci.edu / files/images / 2017 / MyanmarIndia\%20Mobile\%20Money_OregliaSrinivasan_2017\%20Report_FINAL.pdf

Oreglia, Elisa and Janaki Srinivasan. 2019. "Human and non-human intermediation in rural agricultural markets." Journal of Cultural Economy.

Parker, Ian. 2011. "The I.D. Man." The New Yorker, October 3, 2011. https: / / www.newyorker.com/magazine/2011/10/03/the-i-d-man

Ramakumar, R. 2011. "Aadhaar: on a platform of myths." The Hindu, Jul 17, 2011.

Ramanathan, Usha. 2017."A shaky Aadhaar," The Indian Express, Mar 30, 2017;

Roitman, Janet. 1990. "The politics of informal markets in sub-Saharan Africa." Journal of Modern African Studies 28(4), 671-696.

Roitman, Janet. 2012. "Crisis." Political Concepts: A Critical Lexicon (1). Tel Aviv, New York.

Sayer, Andrew. 2000. "Moral Economy and Political Economy." Studies in Political Economy 61, Springer.

Sharma, Aman. 2016."World Bank approaches Unique Identification Authority of India to share its experiences with other countries." The Economic Times, Sep 9, 2016. https:/ / economictimes.indiatimes.com/news/politics-and-nation/world-bankapproaches-unique-identification-authority-of-india-to-share-its-experiences-with-othercountries/articleshow / 54204185.cms

Sharma, Shantanu. 2010. "Aadhar provides national portability: Nandan Nilekani" Economic Times, Nov 28, 2010, https://economictimes.indiatimes.com/tech/software/aadharprovides-national-portability-nandan-nilekani/articleshow / 7003656.cms

Singha, Radhika. 2000. "Settle, Mobilize, Verify: Identification Practices in Colonial India." Studies in History 16 (2): 151-198. 
Sriraman, Tarangini. 2018. In Pursuit of Proof: A History of Identity Documents in India. New Delhi: Oxford University Press.

Srinivasan, Janaki and Aditya Johri. 2013. "Creating Machine Readable Men: Legitimizing the 'Aadhaar' Mega E-Infrastructure Project in India." In IEEE Proceedings of the 6th International Conference on Information and Communication Technologies for Development, Cape Town.

Srinivasan, Janaki, Savita Bailur, Emrys Schoemaker, and Sarita Seshagiri. 2018. "The Poverty of Privacy: Understanding Privacy Trade-Offs From Identity Infrastructure Users in India." International Journal of Communication 12, 1-20.

Srivatsa, Sharath. 2020. "Reverse migration during COVID-19 lockdown exposes chinks in PDS." The Hindu, April 5, 2020. https: / / www.thehindu.com/news/national/karnataka/ reverse-migration-duringcovid-19-lockdown-exposes-chinks-in-pds / article31263564.ece

Staehelin, Konrad. 2019. "As remittance market reaches saturation, mobile money keeps growing" Frontier Myanmar, 09 November 2019, https:// frontiermyanmar.net/en/asremittance-market-reaches-saturation-mobile-money-keeps-growing

Standage, Tom. 1999. The Victorian Internet: The remarkable story of the telegraph and the nineteenth century's online pioneers. $\mathrm{W}$ and $\mathrm{N}$.

Sukumar, Arun Mohan. 2019. Midnight's Machines: A Political History of Technology in India. Viking.

Thaker, Aria. 2018. "The New Oil. Aadhaar's mixing of public risk and private profit." The Caravan, 1 May 2018. https:// caravanmagazine.in/reportage/aadhaar-mixing-publicrisk-private-profit

Thein, M. 2004. Economic development of Myanmar. Institute of Southeast Asian Studies.

Thompson, E.P. 1971. "The Moral Economy of the English Crowd in the Eighteenth Century." Past and Present. 50: 76-136.

Trautwein, C. 2016. “Mobile Money Regulations Released." Myanmar Times 6 April 2016, https:// www.mmtimes.com/business/technology/19851-mobile-money-regulationsreleased.html

Turnell, S. 2009. Fiery dragons: Banks, moneylenders and microfinance in Burma (No. 114). NIAS Press.

UNDP. 2016. Human Development Report 2016: Human Development for Everyone. New York: UNDP.

World Bank. 2018. Principles on identification for sustainable development: toward the digital age (English). Washington, D.C.: World Bank Group.

World Bank. 2018. The Global Findex Database 2017. Washington, D.C.: World Bank Group. https://globalfindex.worldbank.org/ 